\title{
ЗМІНИ ЦИТОКІНОВОГО ПРОФІЛЮ КРОВІ ЩУРІВ ЗА УМОВ СПІЛЬНОЇ ДІЇ НАНОЧАСТИНОК ДІОКСИДУ КРЕМНІЮ I ХІМІЧНОГО ТОКСИКАНТА АЦЕТАТУ СВИНЦЮ
}

\begin{abstract}
Резюме. Здатність посилювати транспорт хімічних речовин і лікарських засобів у клітини та через бар'єри організму, характерна для наночастинок, робить актуальним питання про можливість потенціювання токсичної дії хімічних контамінантів при їх сумісному надходженні в організм із наночастинками.

Мета дослідження - оцінити інтегральний есект наночастинок діоксиду кремнію і хімічного токсиканта ацетату свинцю на цитокіновий профріль сироватки крові.

Матеріали і методи. Досліди проведено на 40 безпородних білих щурах-самцях масою 150-160 г, яких поділили на 4 групи. Тваринам першої (контрольної) групи щоденно внутрішньошлунково вводили фізіологічний розчин. щури другої групи отримували колоїдний розчин наночастинок діоксину кремнію в дозі 50 мг/кг маси тіла. Тваринам третьої групи вводили ацетат свинцю у вигляді водного розчину в дозі 20 мг/кг маси тіла (у перерахунку на свинець), четвертої - щоденно вводили розчин наночастинок діоксиду кремнію сумісно з ацетатом свинцю протягом 3-х тижнів у вищезазначених дозах. В сироватці крові щурів визначали концентрацію цитокінів TNF- $\alpha$, IL-1 $\beta$, IL-6, IL-4, IL-10 методом імуносерментного аналізу. Отримані показники обробляли статистично.

Результати досліджень та їх обговорення. Встановлено, що під впливом наночастинок діоксиду кремнію досліджувані показники не зазнавали достовірних змін. У сироватці крові щурів, яким вводили ацетат свинцю, встановлено значне збільшення концентрації прозапальних цитокінівTNF- $\alpha$, IL-1ß, IL-6 і зниження рівня протизапальних IL-4 и IL-10. Найбільш суттєво цитокіновий профріль змінювався у сироватці крові тварин на фоні сумісного введення наночастинок діоксиду кремнію й ацетату свинцю. У цьому випадку концентрація TNF- $\alpha$, IL-1 $\beta$ та IL-6 була достовірно вищою на 27; 18,8 і 36,9 \% (p<0,05) відповідно, а вміст IL-4 i IL-10 достовірно зменшувався на 25,8 і 24,7 \% (p<0,05) відповідно, порівняно з групою тварин, яким вводили тільки хімічний токсикант.

Висновки. Наночастинки діоксиду кремнію посилюють здатність хімічного токсиканта ацетату свинцю підвищувати продукцію прозапальних цитокінів та знижувати продукцію протизапальних цитокінів.
\end{abstract}

Ключові слова: наночастинки; діоксин кремнію; ацетат свинцю; цитокіни.

ВСТУП На сьогодні відомо, що інтенсивний розвиток нанотехнологій може спричинити як позитивний, так і негативний вплив на довкілля та здоров'я людей [1]. При розгляді потенційної небезпеки наноматеріалів слід враховувати унікальні особливості, зумовлені їх нанорозмірним станом [2]: збільшення хімічного потенціалу веде до зміни розчинності, реакційної і каталітичної здатності; велика питома поверхня наноматеріалів збільшує адсорбційну ємність, хімічну реакційну здатність; невеликі розміри і різноманітність форм наночастинок дозволяють їм зв'язуватися з нуклеїновими кислотами, білками, вбудовуватися в мембрани, проникати в клітинні органели, змінювати фуункції біоструктур; висока адсорбційна здатність наночастинок може полегшувати проникнення всередину клітини різних контамінантів, тим самим підвищуючи їх токсичність.

Одним із пріоритетних видів наноматеріалів $€$ наноструктурний високодисперсний аморфний діоксид кремнію $\left(\mathrm{SiO}_{2}\right)$, експозиція людини до якого постійно збільшується, оскільки нанокремній залишається найперспективнішим матеріалом для сучасної напівпровідникової індустрії, медицини, косметології та харчової промисловості $[3,4]$.

Дані щодо токсичного впливу наночастинок діоксиду кремнію є суперечливими [5]. Кілька досліджень in vitro продемонстрували, що мезопористі [6] та колоїдні наночастинки $\mathrm{SiO}_{2}$ [7] не впливають на життєздатність клітин або цілісність плазматичної мембрани при концентраціях, достатніх для потенційних фрармакологічних застосувань. Проте в інших дослідженнях було підтверджено цитоток- сичність наночастинок діоксиду кремнію, яка була залежною від часу введення, дози введення та розмірів наночастинок [8]. Дані про токсичність наночастинок діоксиду кремнію in vivo $€$ ще більш суперечливими. 3окрема, Kumar et al. [9] показали повне виведення органічно модифікованих наночастинок діоксиду кремнію розміром 20-25 нм 3 організму миші. Цей кліренс відбувався через екскрецію гепатобіліарною системою протягом 15 днів після одноразової внутрішньовенної інфузії, без ознак органної токсичності. На противагу цьому, Xie et al. [10], використовуючи частково аналогічну експериментальну модель, продемонстрували ураження печінки (некроз гепатоцитів та мононуклеарну інорільтрацію), що супроводжувалося циркуляцією наночастинок діоксиду кремнію у ретикулоендотеліальній системі більше 30 днів. Відмінності у гепатотоксичних ефектах, крім інших чинників, можуть пояснюватися відмінними характеристиками розміру частинок та поверхневого заряду [11].

Крім того, наночастинки мають властивість проходити крізь біологічні бар'єри в межах організму, які непроникні для більших частинок [12]. При цьому адсорбовані на їх поверхні токсини можуть проникати у внутрішнє середовище клітини або впливати на мембранні циторецептори, ініціюючи імунну реакцію [13], що зумовлює актуальність вивчення токсикологічних властивостей наночастинок при їх надходженні в організм разом із традиційними контамінантами довкілля, такими як, наприклад, іони важких металів (зокрема свинець).

В Україні одним із важливих джерел інтоксикації залишається тетраетилсвинець і окиси свинцю, що утво- 
рюються в процесі згоряння палива та наявні у викидах промислових підприємств. Крім того, небезпека шкідливого впливу свинцю на здоров'я населення набула особливої актуальності після аварії на Чорнобильській АЕС, під час ліквідації якої використано сотні тисяч тон металу, що при високій температурі на місці його застосування випаровувався і надходив у навколишнє середовище у вигляді аерозолів конденсації $[14,15]$

На сьогодні питання про біологічні ефекти наночастинок при їх надходженні в організм разом із традиційними токсикантами залишаються недослідженими.

Метою дослідження було оцінити інтегральний ефеект наночастинок діоксиду кремнію і хімічного токсиканта ацетату свинцю на цитокіновий профріль сироватки крові.

МАТЕРІАЛИ I МЕТОДИ Досліди проведено на 40 безпородних білих щурах-самцях масою 150-160 г, яких утримували на стандартному раціоні віварію. Усі тварини перебували в однакових умовах і досліджувалися в один і той же час (зберігалась сезонність та час доби).

Піддослідних тварин було поділено на такі групи: перша - інтактні щури (контроль); друга - щури, яким щоденно внутрішньошлунково вводили колоїдний розчин наночастинок $\mathrm{SiO}_{2}$ в дозі 50 мг/кг маси тіла тварини протягом 3-х тижнів; третя - тварини, яким щоденно внутрішньошлунково вводили ацетат свинцю у вигляді водного розчину в дозі 20 мг/кг маси тіла (у перерахунку на свинець) протягом 3-х тижнів для відтворення моделі підгострої свинцевої інтоксикації; четверта - щури, яким щоденно вводили розчин наночастинок $\mathrm{SiO}_{2} 3$ ацетатом свинцю протягом 3-х тижнів у вищезазначених дозах [16]. Інтактним тваринам щоденно внутрішньошлунково вводили відповідну кількість фрізіологічного розчину.

В експерименті використовували аморфний нанопорошок діоксиду кремнію ( $\left.\mathrm{SiO}_{2}, 99+\%, 20-30 \mathrm{~nm}\right)$ виробництва "US Research Nanomaterials, Inc." (США). Диспергування наночастинок у дистильованій воді проводили за допомогою ультразвукового диспергатора УЗДН-М750Т (20-25 кГц, 750 Вт) протягом 5 хв. Як модельний токсикант, використовували ацетат свинцю виробництва "Макрохім" (Україна).

Евтаназію щурів здійснювали шляхом кровопускання за умов тіопентал-натрієвого наркозу через 21 добу від початку досліду. Всі маніпуляції з експериментальними тваринами проводили із дотриманням правил відповідно до Європейської конвенції про захист хребетних тварин, що використовуються для дослідних та інших наукових цілей (Страсбург, 1986) [17].

Визначення концентрації цитокінівTNF- $\alpha$, IL-1 $\beta$, IL-6, IL-4, IL-10 у сироватці крові щурів проводили методом імуноферментного аналізу з використанням наборів реагентів "Bioscience" виробництва "Bender MedSystems GmbH”, Австрія. Абсорбцію проб вимірювали на апараті "StatFax 303 Plus" відповідно до протоколу виробника. Концентрацію цитокінів виражали у пг/мл.

Статистичну обробку цифрових даних здійснювали за допомогою програмного забезпечення Excel (Microsoft, США) та STATISTICA 6.0 (Statsoft, США) з використанням непараметричних методів оцінки одержаних даних. Для всіх показників розраховували значення середньої арифрметичної вибірки (М), її дисперсії і помилки середньої (m). Достовірність різниці значень між незалежними кількісними величинами визначали за допомогою критерію Манна-Уїтні. Зміни вважали статистично достовірними при $р<0,05$.

РЕЗУЛЬТАТИ ДОСЛІДЖЕНЬ ТА ЇХ ОБГОВОРЕННЯ Результати наших досліджень показали, що тритижневе введення щурам колоїдного розчину наночастинок $\mathrm{SiO}_{2}$ у дозі 50 мг/кг маси тіла не викликало достовірних змін цитокінового профрілю сироватки крові (табл.).

На відміну від групи щурів, які отримували наночастинки $\mathrm{SiO}_{2}$, внутрішньошлункове введення ацетату свинцю зумовило виражені зміни усіх досліджуваних показників. Так, концентрація фрактора некрозу пухлин- $\alpha$ у сироватці крові достовірно зростала у 2,4 раза порівняно 3 контрольною групою тварин. Підвищення рівня TNF- $\alpha$, ймовірно, вказує на запальний компонент та активацію моноцит/макрофагальної системи. Вплив TNF- $\alpha$ на клітини реалізується через рецептори двох типів - першого типу (gp 55, CD 120a, TNFa-RI) і другого типу (gp 75, CD 120b, TNFa-RII). Взаємодія TNF- $\alpha$ з рецепторами зумовлює активацію фракторів транскрипції, які є регуляторами генів широкого спектра медіаторів, таких, як ІЛ-1, ІЛ-6, ІЛ-8, простагландини, фрактор активації тромбоцитів, тромбоцитарний фактор росту, а також гормони [18].

Концентрація прозапального IL-1ß при внутрішньошлунковому введенні ацетату свинцю достовірно зростала у 4,2 раза, порівняно з контрольною групою тварин, а концентрація IL-6 - у 2,1 раза. Значне підвищення кон-

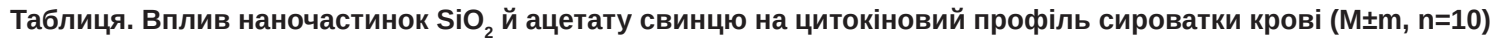

\begin{tabular}{|c|c|c|c|c|}
\hline \multirow{2}{*}{ Показник } & \multicolumn{3}{|c|}{ Група тварин } \\
\cline { 2 - 5 } & контроль & наночастинки $\mathrm{SiO}_{2}$ & ацетат свинцю & $\begin{array}{c}\text { наночастинки } \mathrm{SiO}_{2}+\text { ацетат } \\
\text { свинцю }\end{array}$ \\
\hline $\begin{array}{c}\text { TNF- } \alpha \\
\text { (пг/мл) }\end{array}$ & $8,20 \pm 0,76$ & $8,86 \pm 0,85$ & $19,76 \pm 0,84^{*}$ & $25,10 \pm 1,19^{* * \$}$ \\
\hline $\begin{array}{c}\mathrm{IL}-1 \beta \\
\text { (пг/мл) }\end{array}$ & $9,10 \pm 0,55$ & $10,16 \pm 0,75$ & $38,21 \pm 1,48^{*}$ & $8,38 \pm 1,98^{* * \$}$ \\
\hline $\begin{array}{c}\mathrm{IL}-4 \\
\text { (пг/мл) }\end{array}$ & $19,40 \pm 1,43$ & $20,02 \pm 1,65$ & $11,14 \pm 0,68^{*}$ & $19,14 \pm 0,81^{* * \$}$ \\
\hline $\begin{array}{c}\mathrm{IL}-6 \\
(п г / \mathrm{M})\end{array}$ & $6,50 \pm 0,31$ & $6,79 \pm 0,36$ & $13,98 \pm 0,71^{*}$ & $5,94 \pm 0,35^{* * \$}$ \\
\hline $\begin{array}{c}\mathrm{IL}-10 \\
(п г / \mathrm{M})\end{array}$ & $16,18 \pm 1,56$ & $17,06 \pm 1,85$ & $7,89 \pm 0,47^{*}$ & \\
\hline
\end{tabular}

Примітки: 1) * - зміни достовірні порівняно з показниками контрольних тварин $(p<0,05)$;

2) \# - зміни достовірні порівняно з показниками тварин, яким вводили наночастинки $\mathrm{SiO}_{2}(p<0,05)$;

$3)^{\$}$ - зміни достовірні порівняно з показниками тварин, яким вводили ацетат свинцю $(p<0,05)$. 
центрації прозапальних цитокінів у сироватці крові щурів із свинцевою інтоксикацією, отримане в наших дослідженнях, узгоджується із даними інших авторів $[19,20]$.

Вивчення концентрації протизапальних цитокінів сироватки крові при внутрішньошлунковому введенні ацетату свинцю показало зниження їх продукції, що може відігравати важливу роль у патогенезі свинцевої інтоксикації і бути наслідком активації клітин макрофагальної системи та запуску метаболічних каскадних реакцій.

Такий дисбаланс цитокінового профрілю може бути зумовлений оксидативним стресом, який є важливим механізмом цитотоксичності свинцю і реалізується двома метаболічними шляхами - генерацією активних форм кисню і виснаженням антиоксидантної системи. Окрім взаємодії із сульфгідрильними групами, свинець також може замінювати іони цинку, які є важливими кофакторами для антиоксидантних фрерментів [21]. Оксидативний стрес активує специсрічні шляхи внутрішньоклітинної передачі сигналу, в тому числі мітогенактивовану протеїнкіназу і ядерний фрактор каппа В. Якщо наявне виснаження антиоксидантного захисту з подальшим вивільненням цитокінів і розвитком запалення, то генеруються активні фрорми кисню із клітин запалення (наприклад нейтрофільних гранулоцитів) і утворюється так зване хибне коло [22].

Найбільш суттєво цитокіновий профріль змінювався у сироватці крові тварин, яким вводили наночастинки діоксиду кремнію сумісно з ацетатом свинцю. Так, концентрація фрактора некрозу пухлин- $\alpha$ зросла у 3,1 раза $(p<0,05), I L-1 \beta$ - у 5,0 рази $(p<0,05), I L-6$ - у 2,9 раза $(p<0,05)$. При порівнянні даних показників з результатами, отриманими у третій експериментальній групі, виявлено їх достовірне переважання на 27; 18,8 і 36,9 \% відповідно. щодо концентрації протизапальних цитокінів, то вміст IL-4 достовірно зменшився у 2,3 раза, a IL-10 - у 2,7 раза $(p<0,05)$ порівняно 3 контрольною групою тварин. При порівнянні даних показників із результатами, отриманими у третій експериментальній групі, виявлено їх достовірне зменшення на 25,8 і 24,7 \% відповідно.

Наночастинки діоксиду кремнію за рахунок своїх малих розмірів можуть проникати через біологічні мембрани в клітини, тим самим транспортувати адсорбовані на їх поверхні токсиканти, у тому числі свинець, і посилювати його біодоступність. Крім того, можлива сумісна прозапальна дія свинцю і наночастинок. Відомо, що наночастинки здатні генерувати активні форми кисню, що пов'язано з наявністю прооксидантних функціональних груп на їх реактивній поверхні або із їх взаємодією $з$ клітиною [23]. Як in vitro, так i in vivo дослідження 3 наночастинками кремнію показали, що вони здатні генерувати активні фоорми кисню, а отже, активувати прозапальні реакції [24]. Запальні реакції, що проявилися підвищеною концентрацією інтерлейкіну-1 $\beta$, були виявлені за умови застосування більш дрібних частинок, коли вони поглиналися макрофагами, отриманих із кісткового мозку миші [25].

Важливо зазначити, що запалення безпосередньо спричиняє токсичність та сприяє смерті клітини через індукцію токсичних побічних продуктів запалення, таких як активні форми кисню та білки комплементу, а також через рецепторіндуковані процеси апоптозу/некрозу [26]. Оксидативний стрес також зумовлює вивільнення прозапальних медіаторів через метаболічні каскади, такі, як ядерний срактор каппа В, мітогенактивована протеїнкіназа та фросфроінозитид-3-кіназа [27], що доводить взаємозв'язок між оксидативним стресом і запаленням.

ВИСНОВКИ Наночастинки діоксиду кремнію посилюють здатність хімічного токсиканта ацетату свинцю підвищувати продукцію прозапальних цитокінів та знижувати продукцію протизапальних цитокінів.

\section{СПИСОК ЛІТЕРАТУРИ}

1. Вплив наночасток металів та їх оксидів на організми та екосистеми / В. Ф. Бабій, О. Є. Кондратенко, М. В. Артисюк // Гігієна населених місць. - 2011. - № 57. - С. 438-442.

2. Соловьев С. Н. Нано-Вызовы: социально-экологический аспект / С. Н. Соловьев, С. Ж. Боду // Наукові праці. Серія: Техногенна безпека. - 2010. - Т. 137, № 124. - С. 33-41.

3. Нові можливості застосування наночастинок кремнію у медицині та фрармації / І. С. Чекман, Л. І. Казак, О. В. Ніцак, Є. Ф. Воронін // Вісник фрармакології та фрармації. - 2010. - № 4. - C. 8-14.

4. Presence of nano-sized silica during in vitro digestion of foods containing silica as a food additive / R. Peters, E. Kramer, A. G. Oomen [et al.] // ACS Nano. - 2012. - Vol. 6. - P. 2441-2451.

5. In vivo toxicity of intravenously administered silica and silicon nanoparticles / S. Ivanov, S. Zhuravsky, G. Yukina [et al.] // Materials. - 2012. - Vol. 5. - P. 1873-1889.

6. Mesoporous silica nanoparticles as controlled release drug delivery and gene transfect ion carriers / I. I. Slowing, J. L. ViveroEscoto, C. W. Wu, V. S. Lin // Adv. Drug Deliv. Rev. - 2008. Vol. 60. - P. 1278-1288.

7. SiO2 nanoparticles biocompatibility and their potential for gene delivery and silencing / M. A. Malvindi, V. Brunetti, G. Vecchio [et al.] // Nanoscale. - 2012. - Vol. 4. - P. 486-495.

8. In vitro toxicity of silica nanoparticles in myocardial cells / Y. Y. Ye, J. W. Liu, M. C. Chen [et al.] // Environ. Toxicol. Pharmacol. - 2010. - Vol. 29. - P. 131-137.
9. In vivo biodistribution and clearance studies using multimodal organically modified silica nanoparticles / R. Kumar, I. Roy, T. Y. Ohulchanskky [et al.] // ACS Nano. - 2010. - Vol. 4. P. 699-708.

10. Biodistribution and toxicity of intravenously administered silica nanoparticles in mice / G. Xie, J. Sun, G. Zhong [et al.] // Arch. Toxicol. - 2010. - Vol. 84. - P. 183-190.

11. Effect of surface charge on nano-sized silica particle-induced liver injury / K. Isoda, T. Hasezaki, M. Kondoh [et al.] // Pharmazie. - 2011. - Vol. 66. - P. 278-281.

12. Ryman-Rasmussen J. P. Penetration of intact skin by quantum dots with diverse physicochemical properties / J. P. RymanRasmussen, J. E. Riviere, N. A. MonteiroRiviere // Toxicol. Sci. 2006. - Vol. 91. - P. 159-165.

13. The importance of an endotoxin-free environment during the production of nanoparticles used in medical applications / $\mathrm{H}$. Vallhov, J. Qin, S. M. Johansson [et al.] // Nano Lett. - 2006. - Vol. 6. P. 1682-1686.

14. Гордієнко В. В. Вікові особливості екологічно обумовленого накопичення важких металів в органах інтактних лабораторних щурів / В. В. Гордієнко, Р. Б. Косуба // Клінічна та експериментальна патологія. - 2016. - Т. XV, №3 (57). - С. 26-29.

15. Свинцева небезпека в Україні: сучасні реалії, проблеми та шляхи вирішення / І. М. Трахтенберг, С. П. Луговський, Н. М. Дмитруха [та ін.] // Науковий журнал МОЗ України. - 2013. - № 3 (4). - С. 50-60. 
16. Порядок и методы оценки воздействия искусственных наночастиц и наноматериалов на токсическое действие химических веществ : метод. рек. / [Г. Г. Онищенко, В. А. Тутельян, И. В. Гмошинский и др.]. - М. : Федеральный центр гигиены и эпидемиологии Роспотребнадзора, 2011. - 39 с.

17. European convention for the protection of vertebrate animals used for experimental and other scientific purposes. - Council of Europe. Strasbourg. - 1986. - № 123. - 52 p.

18. Прохоренко Т. С. Система фрактора некроза опухолей $\alpha$ в патогенезе аутоиммунного сахарного диабета / Т. С. Прохоренко, Т.В.Саприна, Ф.Э.Лазаренко [и др.] // Бюллетень сибирской медицины. - 2011. - № 1. - С. 64-69.

19. Offor S. J. Lead induced hepato-renal damage in male albino rats and effects of activated charcoal / S. J. Offor, H. O. C. Mbagwu, O. E. Orisakwe // Front. Pharmacol. - 2017. - Vol. 8. - P.107.

20. Immunomodulation by Lead / V. K. Singh, K. P. Mishra, R. Rani [et al.] // Immunologic Research. - 2003. - Vol. 28/2. P. 151-165.
21. Flora G. Toxicity of lead: a review with recent updates / G. Flora, D. Gupta, A. Tiwari // Interdiscip. Toxicol. -2012. - Vol. 5. - P. 47-58.

22. Чекман I.C. Нанонаука в Україні: до проблеми дослідження. (Історичний аспект і сучасність) / І.С. Чекман // Современные проблемы токсикологии. - 2011. - № 1/2. - С. 16-21.

23. Nanotoxicity: an interplay of oxidative stress, inflammation and cell death / P. Khanna, C. Ong, B. H. Bay, G. H. Baeg // Nanomaterials. - 2015. - Vol. 5. - P. 1163-1180.

24. Park E.-J. Oxidative stress and pro-inflammatory responses induced by silica nanoparticles in vitro and in vitro / E.-J. Park, K. Park // Toxicol. Lett. - 2009. - Vol. 184. - P. 18-25.

25. Effect of silica particle size on macrophage inflammatory responses / T. Kusaka, M. Nakayama, K. Nakamura [et al.] // PLoS One. - 2014. - Vol. 9(3). - P. e92634.

26. Wallach D. Concepts of tissue injury and cell death in inflammation: A historical perspective / D. Wallach, T.-B. Kang, A. Kovalenko // Nat. Rev. Immunol. - 2014. - Vol. 14. P. - 51-59.

27. Nanoparticle-induced pulmonary toxicity / J. J. E. Li, S. Muralikrishnan, C.-T. Ng [et al.] // Exp. Biol. Med. - 2010. Vol. 235. - P. 1025-1033.

Отримано 03.07.17

CI. A. Bandas, I. Ya. Krynytska, M. I. Kulitska, I. P. Kuzmak, M. M. Korda

I. Horbachevsky Ternopil State Medical University

\section{CHANGES OF BLOOD SERUM CYTOKINE PROFILE IN RATS IN RESPONSE TO COMBINED INTRODUCTION OF SILICON DIOXIDE NANOPARTICLES AND CHEMICAL TOXICANT LEAD ACETATE}

Summary. The established capability of nanoparticles to intensify the transport of chemicals and drugs into cells and across the body barriers makes the possibility of potentiating the toxic effects of chemical contaminants in case of their combined introduction into the body with nanoparticles.

The aim of the study - to evaluate the integral effect of silicon dioxide nanoparticles and chemical toxicant lead acetate on blood serum cytokine profile.

Materials and Methods. The experiments were conducted on 40 white outbred male rats, which were divided into 4 groups. The animals of the group 1 (control) were daily administered intragastrically with normal saline. The rats of the group 2 were introduced with colloidal solution of silicon dioxide nanoparticles in a dose of $50 \mathrm{mg} / \mathrm{kg}$ of body weight. The animals of the group 3 were injected with aqueous lead acetate at a dose of $20 \mathrm{mg} / \mathrm{kg}$ of body weight (on a lead basis); and the rats of the group 4 were administered daily with a solution of silicon dioxide nanoparticles and lead acetate during 3 weeks at the abovementioned doses. Concentrations of cytokines TNF- $\alpha$, IL-1 $\beta$, IL-6, IL-4, IL-10 were measured in blood serum of the rats by means of ELISA test.

Results and Discussion. It was established that silicon dioxide nanoparticles did not change significantly the studied indices. In blood serum of the rats administered with lead acetate, a significant increase in the concentration of proinflammatory cytokines TNF- $\alpha$, IL$1 \beta$, IL- 6 and a decrease in the level of anti-inflammatory cytokines IL- 4 and IL-10 were determined. The cytokine profile has been changed the most significantly in blood serum of the animals administrated with both nanoparticles of silicon dioxide and lead acetate. In this case, the concentration of TNF- $\alpha$, IL-1 $\beta$ and IL- 6 was significantly increased by $27,18.8$ and $36.9 \%$ ( $p<0.05$ ) respectively, and the content of IL-4 and IL-10 was significantly decreased by 25.8 and $24.7 \%(p<0.05)$ respectively, compared to the group of animals administered with chemical toxicant only.

Conclusions. Silicon dioxide nanoparticles intensify the capability of chemical toxicant lead acetate to increase proinflammatory cytokines output and reduce the output of anti-inflammatory cytokines.

Key words: nanoparticles; silicon dioxide; lead acetate; cytokines.

(СИ. А. Бандас, И. Я. Криницкая, М. И. Кулицкая, И. П. Кузьмак, М. М. Корда ГВУЗ “Тернопольский государственный медицинский университет имени И. Я. Горбачевского” ИЗМЕНЕНИЯ ЦИТОКИНОВОГО ПРОФИЛЯ КРОВИ КРЫС В УСЛОВИЯХ СОВМЕСТНОГО ДЕЙСТВИЯ НАНОЧАСТИЦ
ДИОКСИДА КРЕМНИЯ И ХИМИЧЕСКОГО ТОКСИКАНТА АЦЕТАТА СВИНЦА

Резюме. Способность усиливать транспорт химических веществ и лекарственных средств в клетки и через барьеры организма, характерная для наночастиц, делает актуальным вопрос о возможности потенциирования токсического действия химических контаминантов при их совместном поступлении в организм.

Цель исследования - оценить интегральный эффрект наночастиц диоксида кремния и химического токсиканта ацетата свинца на цитокиновый профиль сыворотки крови.

Материалы и методы. Опыты проведены на 40 беспородных белых крысах-самцах массой 150-160 г, которые были разделены на 4 группы. Животным первой (контрольной) группы ежедневно внутрижелудочно вводили сризиологический раствор. Крысы второй группы получали коллоидный раствор наночастиц диоксида кремния в дозе 50 мг/кг массы тела. Животным 
третьей группы вводили ацетат свинца в виде водного раствора в дозе 20 мг/кг массы тела (в расчете на свинец), четвертой - ежедневно вводили раствор наночастиц диоксида кремния совместно с ацетатом свинца в течение 3-х недель в вышеупомянутых дозах. В сыворотке крови крыс определяли концентрацию цитокинов TNF-a, IL-1ß, IL-6, IL-4, IL-10 методом иммуноферментного анализа.

Результаты исследований и их обсуждение. Установлено, что под влиянием наночастиц диоксида кремния изучаемые показатели не испытывали достоверных изменений. В сыворотке крови крыс, которым вводили ацетат свинца, установлено

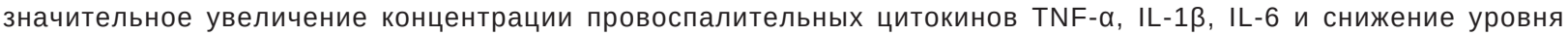
противовоспалительных IL-4 и IL-10. Наиболее существенно цитокиновый профиль менялся в сыворотке крови животных на фроне совместного введения наночастиц диоксида кремния и ацетата свинца. В этом случае концентрация TNF- $\alpha$, IL-1 $\beta$ и IL-6 была достоверно выше на 27; 18,8 и 36,9 \% (p<0,05) соответственно, а содержание IL-4 и IL-10 достоверно уменьшалось на 25,8 и 24,7 \% (p<0,05) соответственно, по сравнению с группой животных, которым вводили только химический токсикант. Выводы. Наночастицы диоксида кремния усиливают способность химического токсиканта ацетата свинца повышать продукцию провоспалительных цитокинов и снижать продукцию противовоспалительных цитокинов.

Ключевые слова: наночастицы; диоксид кремния; ацетат свинца; цитокины. 